\title{
DeSClpher Undergraduate Sciences Competition: Nurturing Interdisciplinary Collaboration
}

Karen M. Zhao, BHSc Student [1]*, Amy Liu, BHSc Student [1], Jessica Moreira, BSc Student [2], Deep Shah, BSc Student [3], Shaheer Nadeem, BHSc Student [1]

[1] Bachelor of Health Sciences Program, McMaster University, Hamilton, Ontario, Canada

[2] Department of Biology, McMaster University, Hamilton, Ontario, Canada

[3] Department of Biochemistry and Biomedical Sciences, McMaster University, Hamilton,

Ontario, Canada

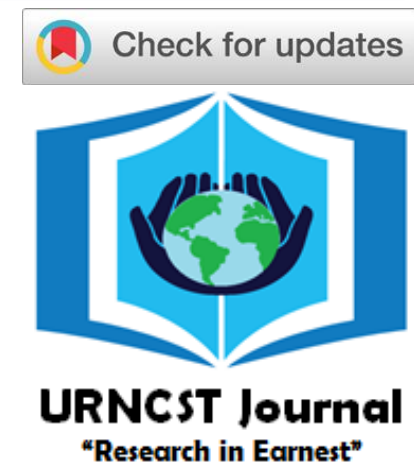

*Corresponding Author: mzhaok13@mcmaster.ca

Abstract: DeSCIpher is one of McMaster University's largest science competitions and encourages interdisciplinary collaboration within the undergraduate community. This editorial will explore the evolution of the competition since its inception in 2016, with a focus on the various challenges and successes encountered by the executive team.

Keywords: DeSCIpher; conference planning; scientific education; case competition

\section{Introduction}

DeSCIpher was founded in 2016 by a team of undergraduate students at McMaster University to address the lack of interdisciplinary collaboration among scientific disciplines. Through group-based competitions, our goal is to attract students from a wide array of disciplines and promote collaborative scientific inquiry. Since its inception, the competition has seen steady growth and has continued to evolve in response to the feedback received from the participants. Changes to competition gameplay (including trivia, jeopardy and case studies) and the expansion of the tested scope of topics have allowed DeSCIpher to reach new audiences. We hope to build on the success of previous competitions to continue to encourage collaboration between often distinct scientific disciplines.

\section{Competition Overview}

Initial iterations of DeSCIpher tested attendees through question and answer periods but has since grown to include more diverse play styles, including Jeopardy rounds and case study elements.

Questions included in the competition can be attributed to six broad categories: psychology, anatomy and physiology, biochemistry, physics, biology, and immunology. These categories have changed from year to year to reflect feedback from participants and improve upon the focus of the competition.

Question and answer periods are split between an individual round and a group round. As the name suggests, the individual round has participants answer questions independently and without the help of their fellow teammates. While on the surface this seems contradictory to the goal of interdisciplinary collaboration, this section is in place to encourage students to form diverse teams prior to registering for the competition. Rather than having a team comprised only of students studying in the same program, this section incentivizes students to connect with others in different faculties in order to maximize the chances of winning.

In response to concerns over the monotony of prolonged question rounds, the organizing committees have introduced a case study component, and more recently, a Jeopardy round.

The case study component, named the Inquiry Challenge, has attendees answering a prompt created by the organizing team. The prompt identifies a relevant topic from that year, and whenever possible, is created with the advice of and inspiration from a faculty member. In the past, the prompts have asked about topics including: novel therapeutic targets, global warming, and antimicrobial resistance. While no correct answer exists for this section, judges, whom are often members of the planning team, evaluate each submitted response based on a previously established rubric.

The Jeopardy round is the most recent innovation to the competition, which was created in response to requests from previous attendees to make the competition more engaging. The hope with this section was also to provide an opportunity for teams that were further behind score-wise to catch up with their peers.

\section{Leadership Structure}

As the competition evolved and grew in scale over time, so too did the structure of the team. While early teams operated without much of a framework, the most current 
UNDERGRADUATE RESEARCH IN NATURAL AND CLINICAL SCIENCE AND TECHNOLOGY (URNCST) JOURNAL Read more URNCST Journal articles and submit your own today at: $\underline{\text { https://www.urncst.com }}$

team has been organized into a number of subcommittees with direct oversight from elected presidents.

\section{President/Co-presidents}

Historically, DeSCIpher has been led by a partnership of two co-presidents; however, it is not crucial for there to be two co-presidents. Depending on the committee, the role can be filled by just one person. For ease of reading, the role will hereinafter be referred to as president. Elected by a democratic voting process, the president is responsible for managing the team and overseeing the organization of the competition. Often the president will have been a previous member of the organizing team, and consequently would have a list of items he/she hopes to improve on with the next competition. These items may be drawn from participant feedback or subjective observations. Once the overarching focus of the competition is decided upon, the president will begin to recruit new members in September. During this process, s/he must be careful to maintain a balance in the number of members in first, second, third or fourth year, so as to ensure the longevity of the team as senior members graduate. After members are finalized, the president must create a timeline to guide the work of the subcommittees. Throughout this process, the president not only delegates tasks, but meets regularly with the subcommittees to promote productivity, troubleshoot problems, and offer insight.

\section{Research Committee}

The research committee consists of interdisciplinary members selected by the president. The committee is an integral part of DeSCIpher, as it is responsible for developing questions of various difficulties for the competition. The questions are based on the six specified interdisciplinary categories and devised using previous knowledge, course material and independent research. The committee is responsible for ensuring the questions remain relevant and up to date based on current research in each category. Members revise questions throughout the planning process to maintain quality and level of difficulty. Over the years, the committee has seen changes in their responsibilities. The committee works now closely with the logistics committee to improve upon the competition each year, with the most recent addition being the jeopardy gameplay. They are also responsible for creating question slides and the interactive gameplay for different rounds throughout the competition.

\section{Logistics Committee}

The logistics committee coordinates the room booking, catering and Inquiry Challenge of the event. Since DeSCIpher is held on the McMaster campus, our logistics committee liaises with university administration to book the required lecture hall and tutorial rooms for the competition. This consists of submitting an Environmental and Occupational Health Support Services form and then speaking with a representative to determine which date and rooms are available for use. The committee also organizes the catering provided at the event, which involves creating the breakfast and lunch menu, ensuring that dietary restrictions are taken into consideration, and communicating closely with the finance committee to guarantee that the catering expense remains within budget. The case study Inquiry Challenge was arranged by the logistics committee this year as well. Various current issues in the scientific and global community were considered before the important topic of antibiotic resistance was selected, to incredible success and reception by our competitors.

\section{Marketing Committee}

The marketing committee designs all of the marketing material and organizes some of the supplies needed for the competition. The DeSCIpher brand has fluctuated throughout the years since its establishment, and our dedicated marketing committee has tested various logos and color schemes the past two years to find a brand that would resonate with what DeSCIpher represents. This year, we have discovered the brand that we will be using for years to come. In addition to logo development, the marketing committee is responsible for managing online advertising, such as social media posts and DeSCIpher's website, and offline advertising, such as posters, campus lawn signs and class visitations. Our social media posts allow us to target our advertising toward students from specific faculties and departments, and our site, developed using SquareSpace, has been a very useful tool for attendees to access up to date information regarding the competition. Posters, campus lawn signs and class visitations serve to promote DeSCIpher's profile around McMaster University in the weeks leading up to the competition and raise awareness about the event. Finally, name tags and certificates are printed and organized by the marketing committee.

\section{Finance Committee}

The finance committee gathers and organizes the funding and sponsorship to cover the expenses of running the competition from the university community. Funds are primarily gathered through sponsorship emails, grant applications and in the future, potential fundraising or by connecting with municipal community sponsors. Sponsorship emails are directed to various science and engineering university faculties and departments, as well as offices and grants on campus that support student initiatives. In the future, we will expand our sponsorship outreach into the greater municipal community and establish various fundraising opportunities in order to improve upon what we can offer in the DeSCIpher experience. Lastly, the committee managed budgets, assets and expenses as well as reimbursements for purchases made by our members on behalf of DeSCIpher. 
UNDERGRADUATE RESEARCH IN NATURAL AND CLINICAL SCIENCE AND TECHNOLOGY (URNCST) JOURNAL Read more URNCST Journal articles and submit your own today at: https://www.urncst.com

\section{Challenges}

By gathering feedback from participants each year, our team has been able to identify new areas of improvement. In 2020, we highlighted three main goals: (i) increasing student participation; (ii) improving the diversity of faculties that participants belonged to; and (iii) developing better communication within the planning team.

DeSCIpher was founded on the belief of promoting interdisciplinary collaboration across various faculties on campus, with the eventual goal of spreading to other universities as well. During the first few years, however, low student turnout and limited funding from sponsors made it difficult to implement the mandate. It was equally challenging to understand where our current operations fell short and how best to improve for the next year. Based on feedback gathered from peers as well as previous attendees, however, we were able to identify our lack of campus presence as one of the largest contributors to low turnout. Despite previous efforts to market through social media and through classroom visitations, the general McMaster population was not aware of our initiative. While Facebook advertising was theoretically a good idea, the site's filtering algorithm often hid our posts and ultimately impeded our marketing campaign. After recognizing this, the 2020 organizing team decided to funnel more funds into purchasing lawn signs and creating stickers for the event. While expensive, these two items were able to drastically increase our campus awareness. Lawn signs were placed strategically all throughout campus, and not only made the DeSCIpher name more recognizable, but helped reach the students who either are not on Facebook or have had our posts filtered out by the site. Similarly, laptop stickers helped expose more students to the DeSCIpher brand and increased awareness for the competition.

In the same vein as low student turnout, we noticed over the years that many of our attendees hailed from either the life science or health science streams. In keeping with our aim to promote interdisciplinary collaboration, we began to actively look for ways to improve the diversity of students that attended our event. It was important to the team, however, to strike a balance between encouraging participation from new streams without discouraging existing streams from attending. This year a new physics category was opened to intentionally attract students from the math and engineering streams.

Finally, communication within the team was another area we sought to improve. Teams in the past have used a group chat on Facebook Messenger as the primary mode of communication, but it was difficult to stay up to date with the chat as Facebook is traditionally used for more casual, recreational purposes. This year, the organizing team used Slack, a business workspace app, to meet our communication needs and it was met with an enthusiastic response. The implementation of Slack allowed our team to deftly organize the communications of each sub-committee into channels, such that messages were categorized and delivered to relevant persons in a manner that was not previously possible. Slack streamlined efficient communication and was key to our success.

The team also found that setting clear expectations earlier in the planning process to be beneficial. The copresidents this year mapped out a timeline with specific dates and deadlines for each sub-team/team member, which helped maintain steady progress throughout the year.

\section{Successes}

Reflecting on DeSCIpher 2020, it is clear that the organizing team has achieved what they had set out to do. This year the number of attendees increased by $200 \%$ and participation has hailed from the most diverse list of programs in the history of DeSCIpher. While participation in previous years was concentrated in the Faculty of Health Science, we now have students studying biology, biochemistry, chemical biology, neuroscience, and engineering attending as well.

In conclusion, we will continue to champion interdisciplinary collaboration and plan future competitions with the same commitment to undergraduate education. The 2020 organizing team offers their sincere best wishes to future planning teams and hopes that this article will be of use in your planning process.

\section{Conflicts of Interest}

The authors declare that they have no conflicts of interest.

\section{Authors' Contributions}

All authors contributed to the development and editing of the editorial.

\section{Acknowledgements}

The authors wish to acknowledge the incredible work of the last five DeSCIpher teams and the Editor, Jeremy $\mathrm{Ng}$, for his continued support of DeSCIpher and this editorial. 
UNDERGRADUATE RESEARCH IN NATURAL AND CLINICAL SCIENCE AND TECHNOLOGY (URNCST) JOURNAL

Read more URNCST Journal articles and submit your own today at: https://www.urncst.com

\section{Article Information}

Managing Editor: Jeremy Y. Ng

Article Dates: Received Mar 02 20; Accepted Apr 21 20; Published May 2620

\section{Citation}

Please cite this article as follows:

Zhao K, Liu A, Moreira J, Shah D, Nadeem S. DeSCIpher Undergraduate Sciences Competition: Nurturing Interdisciplinary

Collaboration. URNCST Journal. 2020 May 26: 4(5). https://urncst.com/index.php/urncst/article/view/185

DOI Link: https://doi.org/10.26685/urncst.185

\section{Copyright}

(C) Karen M. Zhao, Amy Liu, Jessica Moreira, Deep Shah, Shaheer Nadeem. (2020). Published first in the Undergraduate Research in Natural and Clinical Science and Technology (URNCST) Journal. This is an open access article distributed under the terms of the Creative Commons Attribution License (https://creativecommons.org/licenses/by/4.0/), which permits unrestricted use, distribution, and reproduction in any medium, provided the original work, first published in the Undergraduate Research in Natural and Clinical Science and Technology (URNCST) Journal, is properly cited. The complete bibliographic information, a link to the original publication on http://www.urncst.com, as well as this copyright and license information must be included.

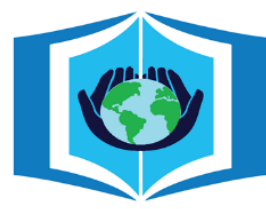

\section{URNCST Journal}

"Research in Earnest"

\section{Funded by the \\ Government \\ of Canada}

\section{Canadà̀}

Do you research in earnest? Submit your next undergraduate research article to the URNCST Journal!

|Open Access | Peer-Reviewed | Rapid Turnaround Time | International |

| Broad and Multidisciplinary | Indexed | Innovative | Social Media Promoted |

Pre-submission inquiries? Send us an email at info@urncst.com | Facebook, Twitter and LinkedIn: @URNCST

Submit YOUR manuscript today at https://www.urnest.com! 